\title{
Publisher Correction: Non-CG DNA methylation-deficiency mutations enhance mutagenesis rates during salt adaptation in cultured Arabidopsis cells
}

Xiaohong Zhu ${ }^{1,2^{*}+}$, Shaojun Xie ${ }^{3 \dagger}$, Kai Tang ${ }^{4}$, Rajwant K. Kalia ${ }^{5}$, Na Liu', Jinbiao Ma ${ }^{7}$, Ray A. Bressan ${ }^{4}$ and Jian-Kang Zhu ${ }^{8}$

Correction to: Stress Biol 1, 12 (2021)

https://doi.org/10.1007/s44154-021-00013-2

Following publication of this article (Zhu et al. 2021), it is noticed that the article contained an error. The affiliation of the author Ray A. Bressan should be below:

4. Department of Horticulture and Landscape Architecture, Purdue University, West Lafayette, IN 47907, USA.

The author Ray A. Bressan's affiliation has been updated in this Correction, and the original article has been updated as well.

\footnotetext{
Author details

'State Key Laboratory of Crop Stress Adaptation and Improvement, School of Life Sciences, Henan University, Kaifeng, China. ${ }^{2}$ State Key Laboratory of Cotton Biology, School of Life Sciences, Henan University, Kaifeng, China. ${ }^{3}$ Bioinformatics Core, Purdue University, West Lafayette, IN 47907, USA. ${ }^{4}$ Department of Horticulture and Landscape Architecture, Purdue University, West Lafayette, IN 47907, USA. ${ }^{5}$ Central Arid Zone Research Institute, Jodhpur 342003, India. ' State Key Laboratory for Managing Biotic and Chemical Threats to the Quality and Safety of Agro-Products, Institute of Vegetables, Zhejiang Academy of Agricultural Sciences, Hangzhou 310021, China. ${ }^{7}$ State Key Laboratory of Desert and Oasis Ecology, Xinjiang Institute of Ecology and Geography, Chinese Academy of Sciences, Urumqi 830011, China. ${ }^{8}$ Shanghai Center for Plant Stress Biology, Shanghai Institutes for Biological Sciences, Chinese Academy of Sciences, Shanghai 200032, China.
}

Published online: 02 December 2021

\section{Reference}

Zhu X, Xie S, Tang K et al (2021) Non-CG DNA methylation-deficiency mutations enhance mutagenesis rates during salt adaptation in cultured Arabidopsis cells. Stress Biol 1:12 https://doi.org/10.1007/s44154-021-00013-2

The original article can be found online at https://doi.org/10.1007/s44154 021-00013-2.

* Correspondence: zhuxiaohong@henu.edu.cn

${ }^{+}$Xiaohong Zhu and Shaojun Xie contributed equally to this work.

'State Key Laboratory of Crop Stress Adaptation and Improvement, School of Life Sciences, Henan University, Kaifeng, China

${ }^{2}$ State Key Laboratory of Cotton Biology, School of Life Sciences, Henan

University, Kaifeng, China

Full list of author information is available at the end of the article

记 Springer
() The Author(s). 2021 Open Access This article is licensed under a Creative Commons Attribution 4.0 International License, which permits use, sharing, adaptation, distribution and reproduction in any medium or format, as long as you give appropriate credit to the original author(s) and the source, provide a link to the Creative Commons licence, and indicate if changes were made. The images or other third party material in this article are included in the article's Creative Commons licence, unless indicated otherwise in a credit line to the material. If material is not included in the article's Creative Commons licence and your intended use is not permitted by statutory regulation or exceeds the permitted use, you will need to obtain permission directly from the copyright holder. To view a copy of this licence, visit http://creativecommons.org/licenses/by/4.0/. 